\title{
Assessment of the energy generation potential of photovoltaic systems in Caribbean region of Colombia
}

\author{
Manuel Fernando ARIZA \\ TABA \\ Solar Energy Institute. Ege University. \\ Izmir, Turkey \\ mftaba@hotmail.com
}

\author{
Mavbuto MWANZA \\ Solar Energy Institute. Ege University. \\ Izmir, Turkey \\ mavbuto_mwanza@yahoo.com
}

\author{
Numan S. ÇETIN \\ Solar Energy Institute. Ege University, \\ Izmir, Turkey \\ ncetin@ rocketmail.com
}

\author{
Koray ÜLGEN \\ Solar Energy Institute. Ege University, \\ Izmir, Turkey \\ Koray.ulgen@ege.edu.tr
}

\begin{abstract}
At present the use of solar energy for power generation has increased in recent years, this is due not only to climate change but also to reduce costs of solar technology materials and equipment. The paper assesses the energy generation potential of photovoltaic systems in the Caribbean region of Colombia based on data extracted from NASA Surface Meteorology and Solar Energy. The solar energy atlas for Caribbean region was generated using ArcGIS program. The analyzed results indicates that in the Caribbean region of Colombia there is a huge energy generation potential of photovoltaic systems with annual electricity generation of $1554.47 \mathrm{kWh} / \mathrm{kW}$ and performance ratio of $79.63 \%$ which is good for PV systems. This study is important as generated results are vital for the development of $P V$ systems in the region and also the results can be used in the future social, economic and environmental impact study for deployment of these systems; and selecting the suitable area and appropriate technology that can adapt to the conditions of this region.
\end{abstract}

Keywords: Photovoltaic systems, Performance ratio, centralized grid connected (CGC), Capacity factor, Final yield.

\section{Introduction}

Today the awareness of the availability of solar energy is necessary for optimal utilization of the resources. Since this energy can be converted into useful energy through use of solar technologies. The case of photovoltaic or thermal systems the purpose is the generation of electricity. The photovoltaic technology has increased considerably year by year. In 2015 the capacity installed was at least $48,1 \mathrm{GW}$, as compared to $40 \mathrm{GW}$ in 2014 [3]. The total photovoltaic capacity installed at the end of 2015 globally amounted to 227,1 GW [3]. The 24 International European Agency (IEA) photovoltaic power systems (PVPS) countries represented $197 \mathrm{GW}$ of cumulative PV installations, the majority of these are grid connected. On the other hand, the non IEA PVPS countries represented $30 \mathrm{GW}$. However, countries with less than GW installed PV system were not included in the global installed capacity. Furthermore, some countries with more than a GW but whose total is difficult to quantify with accuracy were also excluded [3].

Colombia being close to the line of equator, it has regional geographic differences, which defines a number of factors that are specific to the characteristics of incidence of solar radiation. These vary depending on the area or geographical location (mountain or flat). The other factors include; distance from the sea, the average rainfall and conditions of the ground, which leads to a difference for radiation in each region of Colombia.

In the Caribbean region radiation and sunshine have a direct relationship with the values of precipitation (IDEAM) [1]; the lower radiation coincides with the period with more rain and less rain period with higher radiation. At the time when there is less rainfall, solar radiation level is high and represents an average temperature between $38^{\circ} \mathrm{C}$ and $40^{\circ} \mathrm{C}$.

In the year 2015, The Institute of Hydrology, Meteorology and Environment Studies (IDEAM) for Colombia published the third map of solar radiation; this represents an aggregate of maps showing the spatial distribution of solar energy potential in Colombia. These maps show the average global solar radiation per day, average daily sunshine hours and solar ultraviolet radiation on flat surface.

However, despite of the Caribbean region having the highest annual solar radiation in range of $4-5 \mathrm{kWh} / \mathrm{m}^{2}$ day as shown in figure 1 with La Guajira having the greatest solar potential compared with the other regions. However, solar energy for electricity 
generation has not been exploited due to among the reasons few studies on the potential of photovoltaic systems for energy generation. Therefore, the aim of this paper is to study and assess the potential of the photovoltaic systems for energy generation in Caribbean region. Based on this information, it will be possible to quantify the solar energy potential for electricity generation for the Caribbean region. Furthermore, in the case of remote areas, for the national transport networks and energy distribution, this information is significant since it can be used in various projects. In addition, this information can be further be used in various requirement like communication, water pump systems, lighting, signing, heating, air conditioner and use in agriculture. At the same time, the information can also help to identify strategic regions, which are more appropriate for solar energy utilization and development to provide solutions necessary for the population.

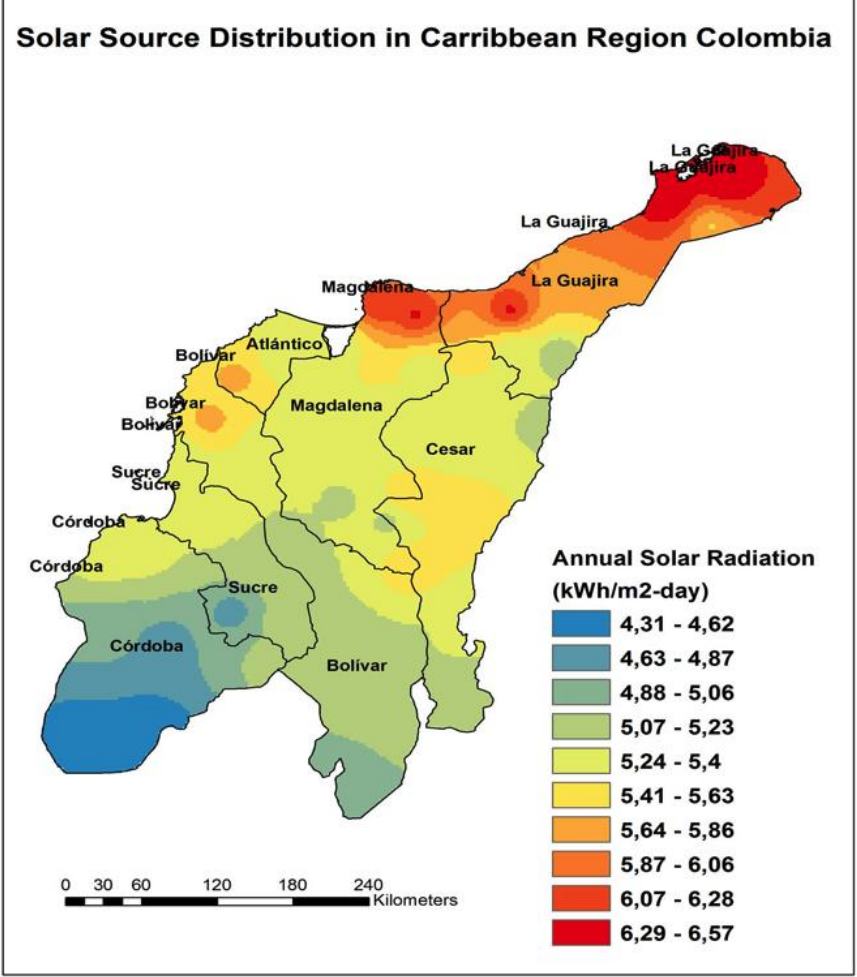

Figure 1. Solar source distribution in Caribbean region in Colombia

\subsection{The status of electricity generation in Colombia}

The main sources of electricity generation in Colombia are hydropower systems, gas, coal, fossil fuels, wind systems and biomass systems. In Colombia the capacity of energy generation by technologies are Hydropower $70.41 \%$, Gas $10.86 \%$, Coal $7.56 \%$, liquids $8.81 \%$, gasliquids $1.78 \%$, wind power $0.12 \%$ and biomass $0.74 \%$. As shown in figure 2 and Table 1 [2].

Table 1. Technology Capacity of Colombia

\begin{tabular}{lcc}
\hline \multicolumn{3}{c}{ Technology Capacity } \\
\hline Technology & Power (MW) & Participation (\%) \\
Hydropower & $10.919,8$ & 70,41 \\
Thermal Gas & $1.684,4$ & 10,86 \\
Thermal Coal & $1.172,0$ & 7,56 \\
Liquids & $1.366,0$ & 8,81 \\
Gas-Liquids & 276,0 & 1,78 \\
Wind & 18,4 & 0,12 \\
Biomass & 72,3 & 0,47 \\
Total & $\mathbf{1 5 . 5 0 8 , 8}$ & $\mathbf{1 0 0}$ \\
\hline
\end{tabular}

However, in month of January of 2015 the national interconnected system showed a decrease of the installed capacity due to the withdrawal of 46MW (Jet A1) from the system [2].

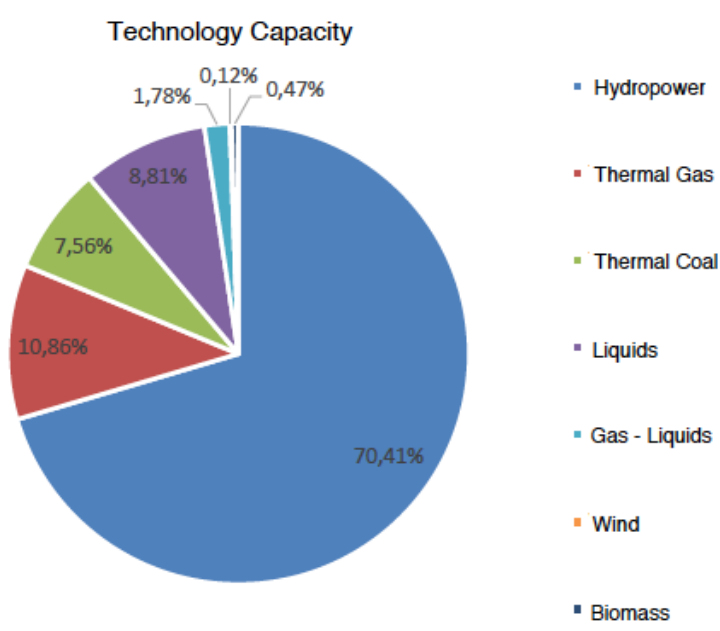

Figure 2. Energy technology Capacity in Colombia [2]

Table 2 shows the installed electric power capacity clustered by regions in terms of the technologies. Table 2 shows that the departments of Atlántico, Bolivar, Córdoba and La Guajira are the highest focal point of power production in the region [2].

Table 2. Technology capacity installed in the Caribbean region by resource type in MW [2]

\begin{tabular}{rcccccrr} 
ACPM & WATER & BIOMASS & COAL & FUEL OIL & GAS & WIND & TOTAL \\
\hline $\mathbf{4 6 2 , 0}$ & $\mathbf{3 3 8 , 0}$ & & $\mathbf{2 9 6 , 0}$ & $\mathbf{2 9 7 , 0}$ & $\mathbf{1 . 3 3 1 , 0}$ & $\mathbf{1 8 , 4}$ & $\mathbf{2 . 7 4 2 , 4}$ \\
153,0 & & & 110,0 & $1.241,0$ & & $1.504,0$ \\
309,0 & & & 187,0 & 90,0 & & 586,0 \\
& 338,0 & & & & \multirow{2}{*}{18,4} & 338,0 \\
& & & & & & 0,0 \\
& & & & & & & 0,0 \\
& & & & & & & \\
\end{tabular}




\section{Material and methods}

In Colombia the energy generation by PV systems are only used for household energy consumption (i.e. small household systems-SHS) and off-grid systems (mini grid) in remote areas where grid connection is not possible. Non-connected zones account for $52 \%$ of the country's area and diesel generators are commonly used to produce energy [4]. The use of diesel generators contribute to greenhouse gas emission and pollution of the environment[4].

In order to assess the energy generation potential of PV systems in Caribbean region of Colombia the following indicators has been used based on previous studies undertaken in other parts of the world [5-15]; performance ratio, capacity factor, final yield, suitable area, Theoretical, Geographical and technical energy potential. The data used in the study has been obtained from NASA Surface Meteorology and Solar Energy.

\subsection{Estimation of PV Electricity Generation Potential}

\subsubsection{Energy Potential}

Theoretical solar energy potential is defined by the radiation energy that reaches a specified area (e.g. 1 $\mathrm{Km}^{2}$ ) within a defined time period (e.g. 1 year). [5]. The theoretical solar energy potential has been determined using the expression (1) [5]:

$$
A E A_{\text {th }}=\mathrm{I} \times \mathrm{A} \times 365
$$

Where $A E A_{t h}$ is the available theoretical potential of annual solar energy $\left(\mathrm{MJ} / \mathrm{m}^{2}\right.$-year $), I$ is the global average solar radiation per day $\left(\mathrm{MJ} / \mathrm{m}^{2}\right.$-day), $A$ is the land area available $\left(\mathrm{m}^{2}\right)$ and 365 is the number of days in a year.

There are two types of grid connected PV system applications:

1) Centralized grid connected (CGC) PV system; perform the functions of centralized stations and generally are systems mounted on the ground and larger than 1MW [6].

2) Decentralized grid connected (DCGC) PV system; normally installed at roof-tops on the buildings or houses or close to houses but small in size $[7,8]$.

The geographical potential can be defined as the theoretical potential limited by suitable area for PV electricity energy generation and development. The geographical solar energy potential has been determined using the expression (2) [5]:

$G P=I \times A_{s} \times 365=A E A_{t h} \times\left(\frac{A_{s}}{A}\right)$

Where $G P$ is the geographical potential of solar energy annual available $\left(\mathrm{MJ} / \mathrm{m}^{2}\right.$-year $), I$ is the global average solar radiation per day $\left(\mathrm{MJ} / \mathrm{m}^{2}\right.$-day $), A_{S}$ is the area considered accessible and suitable $\left(\mathrm{m}^{2}\right)$ for PV system development and 365 is the number of days in a year.

The suitable area for land use are as shown in the table $3[9,10]$. The suitable area for CGC FV systems has been estimated as $66144 \mathrm{~km}^{2}$ which is $3,11 \%$ of the total surface area of Colombia.

\section{Table 3. Total area and total suitable area for CGC PV}

\begin{tabular}{lcc} 
Department & Area $\left(\mathrm{km}^{2}\right)$ & Suitable Area $\left(\mathrm{km}^{2}\right)$ \\
\hline LA GUAJIRA & 20848 & 9446 \\
CESAR & 22905 & 12454 \\
MAGDALENA & 24188 & 9590 \\
ATLÁNTICO & 3388 & 1353 \\
BOLÍVAR & 25978 & 20303 \\
SUCRE & 10670 & 4001 \\
CÓRDOBA & 23980 & 9197 \\
TOTAL & $\mathbf{1 3 2 2 8 8}$ & $\mathbf{6 6 1 4 4}^{1}$ \\
\hline
\end{tabular}

The geographical and technical potential has been estimate by analyzing the available area, social factors and technical limitations.

Technical potential is defined as the part of the theoretical potential available by considering the fundamental restriction for the area utilization such as national parks, agriculture areas, forests, surface water bodies, and many other restricted or protected areas [5]. The technical potential of annual PV electricity generation has been determined using the expression (3)[5]:

$$
E A P=\sum G P \times \eta_{m} \times P R
$$

Where $\eta_{m}$ is the module's conversion efficiency and PR is the PV system's performance ratio. The module's conversion efficiency depends on the type of solar cell and module temperature [5]

\subsubsection{Performance ratio (PR)}

The performance ratio, in some cases called "Quality factor" takes account total system losses such as inverter losses, cable losses, and thermal losses. It is appropriate to know the performance ratio from beginning up to end of the operation of the system, with the purpose of pinpoint causes of yield losses [11,12]. The performance ratio has been estimated using the expression (4), [11,12]:

$$
P R=\frac{E_{A C}}{G_{t} \times \eta_{S T C}}
$$

The performance ratio can also be defined as the ratio between actual yield (i.e. annual production of electricity delivered at AC) and the target yield given by the expression (5), $[13,14,15]$ :

$$
P R=\frac{Y_{f}}{Y_{r}}=\frac{E_{\text {real }}}{E_{\text {ideal }}}=\eta_{\text {deg }} \eta_{\text {tem }} \eta_{\text {soil }} \eta_{\text {inv }}
$$

\footnotetext{
1 The data mentioned were approximate values but this does not ensure that the values correspond to actual data.
} 


\subsubsection{Capacity factor}

The capacity factor can be defined as the ratio between average annual energy output and rated power of the considered module. For PV systems, the capacity factor is given by the expression (6) [16]:

$C F=\frac{E_{A C}}{P_{P V, \text { rated }} \times 8760}$

\subsubsection{Cell temperature}

The cell temperature can be defined as incoming irradiance and the others parameters, $T_{a}$ the maximum ambient temperature, $I$ is the in-plane irradiance and $T_{N O C T}$ is the technology dependent nominal operating cell temperature, $T_{a, N O C T}$ is the ambient reference temperature $\left(20^{\circ} \mathrm{C}\right)$ and $I_{N O C T}$ the cell temperature at irradiance and the value is $1000 \mathrm{~W} / \mathrm{m}^{2}[17,18]$.

$T_{c}=T_{a}+\frac{I}{I_{\text {NOCT }}}\left(T_{\text {NOCT }}-T_{a, N O C T}\right)$

\subsubsection{Module efficiency}

The module efficiency can be estimated as the reference of PV panel efficiency $\eta_{P V}$,ref, the reference temperature $\mathrm{T}_{\text {ref }},\left(25^{\circ} \mathrm{C}\right)$, temperature coefficient of maximum power of the solar cells $\beta$ and $T_{c}$ cell/module temperature [19].

$\eta_{c}=\eta_{P V, r e f}\left(1-\beta\left(T_{C}-T_{r e f}\right)\right.$

\section{Results and Discussion}

In the study the potential of PV systems for energy generation in Caribbean region of Colombia has been carried out using analytical approach. The input technical data used for the assessment are summarized in table 4.

Table 4. Efficiency of the components

\begin{tabular}{lc} 
Components & Efficiency \\
\hline PV efficiency $\left(\boldsymbol{\eta}_{\boldsymbol{P V}}\right)$ & $13,8 \%$ \\
Inverter efficiency $\left(\boldsymbol{\eta}_{\boldsymbol{C P U}}\right)$ & $95 \%$ \\
Others efficiencies ${ }^{2}\left(\boldsymbol{\eta}_{\boldsymbol{o}}\right)$ & $90 \%$ \\
Cables $\left(\boldsymbol{\eta}_{\boldsymbol{D C} / \boldsymbol{A C}}\right)$ & $93 \%$ \\
\hline
\end{tabular}

Monitoring the solar radiation, temperature, and sunshine hours of the study area is very important, since these parameters have influence on the energy generation potential of the PV systems. The average monthly radiation on a horizontal plane to the Caribbean region is shown in Figure 4. The Caribbean region of Colombia has a substantial amount of solar radiation, with the annual average of daily solar radiation of $5.35 \mathrm{kWh} / \mathrm{m}^{2}$-day. The region has the maximum monthly average solar radiation in the month

\footnotetext{
${ }^{2}$ This refers to the temperatures and other losses generated on the photovoltaic panel
}

of March at $5.81 \mathrm{kWh} / \mathrm{m}^{2}$-day and the lowest in the month of November at $4.83 \mathrm{~kW} / \mathrm{m}^{2}$-day. In short the monthly average solar radiation in Caribbean region varies between $4.83 \mathrm{kWh} / \mathrm{m}^{2}$-day and $5.81 \mathrm{kWh} / \mathrm{m}^{2}$-day. The region receives the total annual solar radiation of $1952.75 \mathrm{kWh} / \mathrm{m}$-year with total yearly peak sunshine hours of about 2190 hours, which is suitable for energy generation using PV systems. Thus, with these higher solar radiations being received in the region, makes it more suitable place for power generation from solar energy source. Furthermore, the average annual peak sunshine hour in the Caribbean region of Colombia is 6 hours per day and the maximum average air temperature is $34^{\circ} \mathrm{C}$. [20].

The analyzed results show that, the efficiency of the multi-crystalline silicon module at maximum average air temperature is $11,96 \%$, which correspond to a drop in the module efficiency by $1.84 \%$. In other words, the performance of the PV system in this region is expected to drop due to high temperature. This drop in the module efficiency is as the result of higher temperatures. This drop in the module efficiency translates to loss of approximately 2000TWh of energy per year in the PV system.

The Caribbean region has a total surface area of approximately $132,288 \mathrm{~km}^{2}$ and receives annual average of daily solar radiation of $5.35 \mathrm{kWh} / \mathrm{m}^{2}$-day. Thus, considering the surface area and the average annual solar radiation and using equation 1 , the theoretically solar energy potential for Caribbean region is found to be $258,3325 \mathrm{TWh} / \mathrm{year}$. Thus, the region receives about $258,332 \mathrm{TWh} /$ year of solar energy. Taking into consideration the restricted areas and land areas not suitable for PV system installation. The region have a total of about $66,144 \mathrm{~km}^{2}$ suitable area for PV systems installation. Using equation 2 , the geographical solar energy potential for the region has been estimated at approximately $129,160 \mathrm{TWh} /$ year.

The multi-crystalline silicon with the following specification; nominal output power Pmax of 200Wp, voltage at Pmax of $26.4 \mathrm{~V}$, Current at Pmax of 7.6A, module efficiency of $13.8 \%$ and surface area of $1.45 \mathrm{~m} 2$ was used to evaluate the technical solar energy potential of the Caribbean region. The capacity factor for a multi-crystalline silicon module under the Caribbean region weather condition is found to be $17.75 \%$ and due to temperature effect, the efficiency of the module is found to reduce to $11.96 \%$. Furthermore, the multi-crystalline silicon module is found to have $79.63 \%$ performance ratio and the $1554.47 \mathrm{kWh} / \mathrm{kWp}$ yearly final yield. The total amount of solar energy technical potential for Caribbean region is about 12,301TWh/year. 


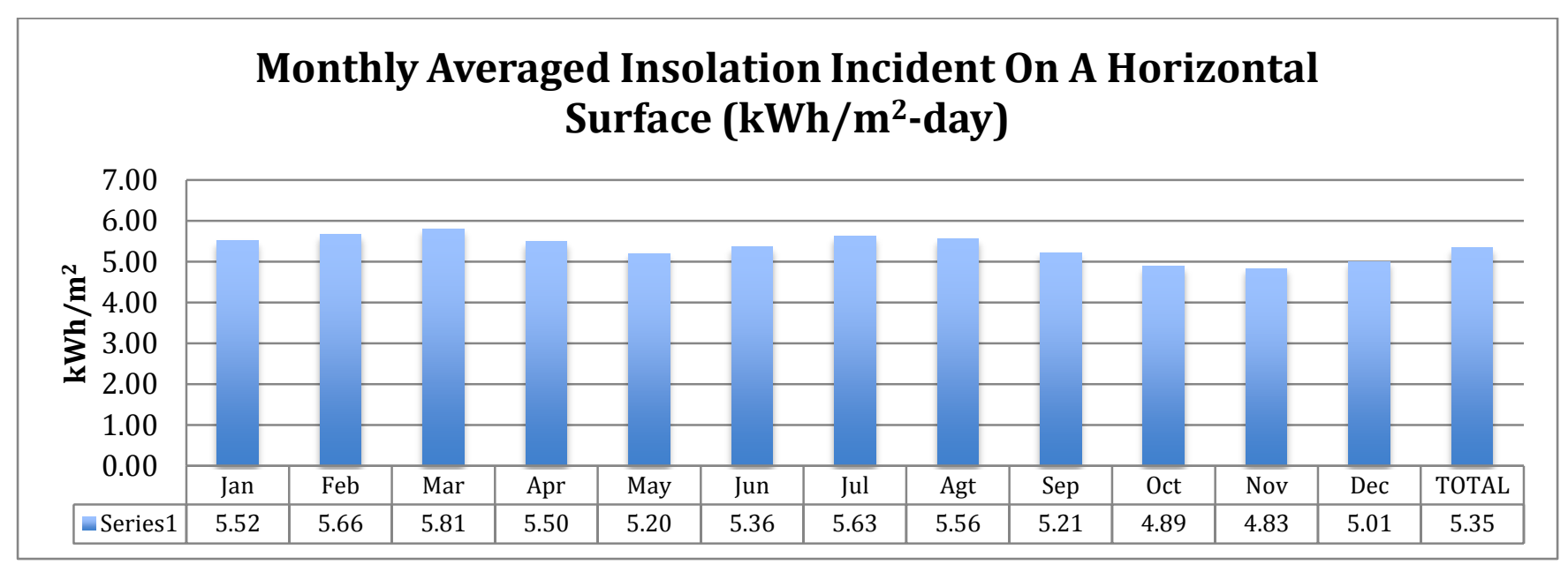

Figure 4. Monthly averaged insolation incident on a horizontal surface [21].

Table 5 below summarizes the results of the study corresponding to solar energy potential in terms of theoretical, geographical and technical potential, and performance indices for the PV system that is performance ratio, capacity factor and the efficiency of the module.

Table 5. Theoretical, geographical and technical potential of CGC PV solar.

\begin{tabular}{lccccccc}
$\begin{array}{c}\text { Theoretical } \\
\text { potential } \\
(\mathrm{TWh} / \mathrm{yr})\end{array}$ & $\begin{array}{c}\text { Module } \\
\text { efficiency } \\
(\%)\end{array}$ & $\begin{array}{c}\text { Geographical } \\
\text { potential } \\
(\mathrm{TWh} / \mathrm{yr})\end{array}$ & $\begin{array}{c}\text { Performance } \\
\text { ratio (PR) } \\
(\%)\end{array}$ & $\begin{array}{c}\text { Capacity } \\
\text { factor } \\
(\%)\end{array}$ & $\begin{array}{c}\text { Final yield } \\
(\mathrm{kWh} / \mathrm{kW})\end{array}$ & $\begin{array}{c}\text { Technical potential } \\
(\mathrm{TWh} / \mathrm{yr})\end{array}$ \\
\hline CGC PV & 258,300 & 11.96 & 129,160 & 79.63 & 17,75 & 1554.47 & $12,300.87$ \\
\hline
\end{tabular}

\section{Conclusion}

The paper has presented the energy generation potential of PV systems in Caribbean region. The region has considerable energy potential and would contribute to power generation that can be used to replace the fossil fuel power plants. As it can be noticed from table 2, more than $50 \%$ of energy generation in the region is from the fossil power plants. The use of solar energy technologies would reduce the environmental, social and cultural impacts that result from the use of fossil fuel for energy generation.

In this paper, the energy output, capacity factor and performance ratio of the photovoltaic systems in the Caribbean region in Colombia has been evaluated using monthly average daily global solar irradiation data available at NASA Surface Meteorology and Solar Energy. Multi-crystalline silicon photovoltaic module had been considered in this study to estimate the solar energy generation potential for Caribbean region. The analyzed results of the study indicates that the multicrystalline silicon module have performance ratio of $79.63 \%$ and capacity factor of $17.75 \%$ under weather condition of Caribbean region. Therefore, the study concludes that $1554.47 \mathrm{kWh}$ electricity can be generated annually from a $1 \mathrm{~kW}_{\mathrm{P}}$ CGC PV system in Caribbean region of Colombia at a performance ratio of $79.63 \%$. Thus, with ever increasing fossil fuel price, air pollution due to use of fossil fuels and droughts affecting the hydropower system in Colombia, Solar energy generation of $\mathrm{PV}$ systems offers the best alternative solution for the Caribbean region and Colombia.

\section{References}

[1] The institute of hydrology, meteorology and environment studies [IDEAM]. (2015). Forecasts and Alerts. Available: <http://www.ideam.gov.co/ >. Accessed: April 2016.

[2] Mining and Power Planning Unit [UPME]. (2015). İnforme mensual de variables de generación y del Mercado Eléctrico Colombiano. Available: <http://www.upme.gov.co/>. Accessed: March 2016.

[3] IEA-PVS Reporting Countries, Becquerel Institute (BE), RTS Corporation (JP) SolarPower Europe (EU).(2016). Snapshot of Global Photovoltaic Markets - IEA PVPS. Available: <http://www.ieapvps.org/index.php?id=trends0>. Accessed: May 2016.

[4] Procolombia. (2015). Electric power in Colombia Investment opportunities - Power Generation. Available: 〈http://www.procolombia.co $>$. Accessed: March 2016.

[5] Nicolai Herrmann. Regional energy 2050 : a sustainability-oriented strategic backcasting methodology for local utilities / Nicolai Herrmann. Mering, Germany: München ; Mering : Hampp, 2011.

[6] Ottmar Edenhofer, Ramón Pichs Madruga, Youba Sokoba. Renewable Energy Soruces and Climate Change Mitigation Special Report of the Intergovernmental Panel on Climate Change. 2012, pp 354. 
<http://www.cambridge.org/9781107607101>. Accessed: May 2016.

[7] Ram Joshi, Maharshi Pathak, Decentralized Gridconnected Power Generation Potential in India: From Perspective of Energy Efficiency Buildings. (2013). Availabe: <http://www.sciencedirect.com>. Accessed: March 2016.

[8] Hanumath Prasad Ikkurti, Suman Saha. A comprehensive techno-economic review of microinverters for Building Integrated Photovoltaics (BIPV). CSIR-Network Institute for Solar Energy, Drives \& Control System Technology Group, CSIRCentral Mechanical Engineering Research Institute, Mahatma Gandhi Avenue, Durgapur 713209, India. Available:

<http://www.sciencedirect.com/science/article/pii/S136 4032115002348>.

[9] National Geographic Portal, (2016). Colombia. Geographic Institute Agustín Codazzi [IGAC]. Available: 〈http://www.igac.gov.co/igac〉.

[10] DaftLogic. Google Maps Area Calculator Tool. Available: < https://www.daftlogic.com/projectsgoogle-maps-area-calculator-tool.htm>.

[11] Eicker U. Solar technologies for buildings. John Wiley and Sons; 2003.

[12] Nakagami H, Ishihar O, Sakai K, Tanaka A. Performance of residential PV system under actual field conditions in western part of Japan. In: International solar energy conference, solar engineering, American Society of Mechanical Engineers; 2003. p. 491-498.

[13] Kymakis E, Kalykakis S, Papazoglou TM. Performance analysis of a grid connected photovoltaic park on the island of Crete. Energy Convers Manage 2009;50(3):433.

[14] Photovoltaic power systems programme. Cost and performance trends in grid connected photovoltaic systems and case studies. IEA-PVPS T2-06; 2007

[15] The German solar energy society. Planning and installing photovoltaic systems: a guide for installers, architects and engineers. UK: James and James; 2006.

[16] Kymakis E, Kalykakis S, Papazoglou TM. Performance analysis of a grid connected photovoltaic park on the Island of Crete. Energy Convers Manage 2009;50(3):433-8.

[17] Markvart T (editor). Solar electricity. 2nd edition. Chichester: Wiley; 2000.

[18] Skoplaki E, Boudouvis AG, Palyvos JA. A simple correlation for the operating temperature of photovoltaic modules of arbitrary mounting. Sol Energ Mat Sol C 2008; 92: p. 1393-1402.

[19]Evans DL, Florschuetz LW. Cost studies on terrestrial photovoltaic power systems with sunlight concentration. Solar Energy 1977;19:255-62.
[20] The institute of hydrology, meteorology and environment studies [IDEAM]. (2015). Forecasts and Alerts.

Available: $<$ http://atlas.ideam.gov.co/visorAtlasClimatol ogico.html>. Accessed: May 2016.

[21] NASA Surface Meteorology and Solar Energy. <https://eosweb.larc.nasa.gov/cgi-

bin/sse/grid.cgi?email=skip@larc.nasa.gov>. 